\title{
Synthesis and characterization of metallic complexes of 3-(2-furyl) 2-propenal semicarbazone with $d$ element dihalides
}

\author{
G. Ibrahim, ${ }^{a}$ M. A. Khan, ${ }^{a}$ P. Richomme, ${ }^{b}$ O. Benali-Baïtich ${ }^{\mathrm{c}}$ and G. Bouet ${ }^{\mathrm{a} *}$ \\ ${ }^{a}$ Laboratoire de Chimie de Coordination, Faculté de Pharmacie, 16 Boulevard Daviers, F-49100 Angers, \\ France \\ ${ }^{\mathrm{b}}$ Service commun de R.M.N., Faculté de Pharmacie, 16 Boulevard Daviers, F-49100 Angers, France \\ ${ }^{\mathrm{c}}$ Laboratoire de Chimie de Coordination, Institut de Chimie, U.S.T.H.B., B.P. 22, El Alia, Bab Ezzouar, \\ DZ-16111 Alger, Algeria
}

(Received 28 June 1996; accepted 4 February 1997)

\begin{abstract}
Furyl) 2-propenal semicarbazone (FASC) and $\mathrm{Co}^{\mathrm{II}}, \mathrm{Ni}^{\mathrm{II}}, \mathrm{Cu}^{\mathrm{II}}, \mathrm{Zn}^{\text {II }}$ and $\mathrm{Cd}^{\mathrm{II}}$ chlorides or bromides gave the complexes: $\left[\mathrm{M}(\mathrm{FASC})_{2} \mathrm{X}_{2}\right],\left[\mathrm{M}(\mathrm{FASC})_{2}\right] \mathrm{X}_{2}$ or $\left[\mathrm{M}(\mathrm{FASC}) \mathrm{X}_{2}\right]$ which were characterized starting from elemental analysis and molar conductances. Their structures are discussed on the basis of magnetic moments, infrared and electronic spectra; in addition, the NMR data are used in the case of $\mathrm{Zn}^{\mathrm{II}}$ and $\mathrm{Cd}^{\mathrm{II}}$ species. The main cell parameters are given using X-ray diffraction powder diagrams. (C) 1997 Elsevier Science Ltd
\end{abstract}

Keywords: complexes; $d$ element; semicarbazone; spectroscopy; furan; X-ray powder diffraction.

We have previously described the complexes formed between various furan oximes and $3 d$ metal dihalides [1]. The coordinating properties of some semicarbazones were studied [2-4] and many papers dealt with various thiosemicarbazone metal complexes [515]. As far as we know, no metallic complexes deriving from 3-(2-furyl) 2-propenal semicarbazone or FASC (see Fig. 1) have been described. In the present paper, we present nine new metal complexes obtained with FASC and $\mathrm{Co}^{11}, \mathrm{Ni}^{11}, \mathrm{Cu}^{\mathrm{II}}, \mathrm{Zn}^{\mathrm{II}}$ and $\mathrm{Cd}^{\mathrm{II}}$ chlorides and bromides. The complexes were characterized using elemental analysis, infrared and electronic spectra

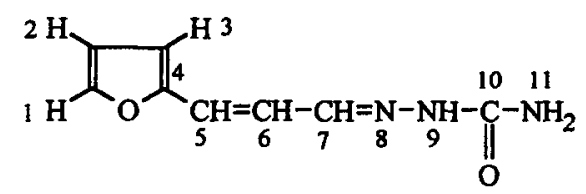

Fig. 1. Structure of FASC.

*Author to whom correspondence should be addressed. and, in addition NMR spectra for diamagnetic species.

\section{EXPERIMENTAL}

Synthesis of the ligand [16]

To an aqueous solution $\left(20 \mathrm{~cm}^{3}\right)$ of semicarbazide hydrochloride $(11.15 \mathrm{~g}, 0.1 \mathrm{~mol})$ and sodium acetate $(20 \mathrm{~g})$ was added dropwise an ethanolic solution (17.9 $\mathrm{g}$ in $20 \mathrm{~cm}^{3}$ ) of $\beta$-furylacrolein (3-(2-furyl) 2propenal). After three hours refluxing, the semicarbazone precipitated down on cooling. It was filtered and finally recrystallized from boiling water (yield $40 \%$ ). The semicarbazone presented satisfactory analysis and spectral properties.

\section{Synthesis of the complexes}

All the complexes were prepared starting from $10^{-2}$ mol $(1.79 \mathrm{~g})$ of FASC dissolved in EtOH (used vol. in brackets). This solution was heated until the solvent 
refluxed and then, the ethanolic solution of the metallic halide was added slowly while stirring. The complexes were removed by filtration, washed with EtOH and $n$-pentane, dried in vacuo over silica gel. The purity of the complexes was verified using thin layer chromatography.

Dichloro bis[3-(2-furyl) 2-propenal semicarbazone] cobalt $(I I)$. To the FASC ethanolic solution $\left(50 \mathrm{~cm}^{3}\right)$ and under refluxing conditions, was added $\mathrm{CoCl}_{2} \cdot 6$ $\mathrm{H}_{2} \mathrm{O}\left(1.2 \mathrm{~g} ; 5.10^{-3} \mathrm{~mol} ; 20 \mathrm{~cm}^{3}\right)$. The reflux is maintained for $4 \mathrm{~h}$ and the volume is reduced by $50 \%$ under reduced pressure.

Dibromo bis[3-(2-furyl)2-propenal semicarbazone] cobalt $(I I)$. The bromo complex was obtained in the same way as the chloro complex starting from FASC $\left(70 \mathrm{~cm}^{3}\right)$ and $\mathrm{CoBr}_{2} \cdot 6 \mathrm{H}_{2} \mathrm{O}\left(1.6 \mathrm{~g} ; 5.10^{-3} \mathrm{~mol} ; 20\right.$ $\mathrm{cm}^{3}$ ).

Dichloro bis[3(2-furyl)2-propenal semicarbazone] nickel(II). It was prepared with FASC $\left(40 \mathrm{~cm}^{3}\right)$ and $\mathrm{NiCl}_{2} \cdot 6 \mathrm{H}_{2} \mathrm{O}\left(1.2 \mathrm{~g} ; 5.10^{-3} \mathrm{~mol} ; 6 \mathrm{~cm}^{3}\right)$ after a $3 \mathrm{~h}$ reflux.

Dibromo bis[3-(2-furyl)2-propenal semicarbazone] nickel(II). To the solution of FASC $\left(70 \mathrm{~cm}^{3}\right)$ was added the solution of anhydrous $\mathrm{NiBr}_{2}\left(1.1 \mathrm{~g} ; 5.10^{-3}\right.$ $\mathrm{mol} ; 28 \mathrm{~cm}^{3}$ ). The complex precipitated down on cooling after $4 \mathrm{~h}$ refluxing.

Dichloro bis[3-(2-furyl) 2-propenal semicarbazone] copper(II). $\mathrm{CuCl}_{2} \cdot 2 \mathrm{H}_{2} \mathrm{O}\left(0.84 \mathrm{~g} ; 5.10^{-3} \mathrm{~mol} ; 25 \mathrm{~cm}^{3}\right)$ was added to FASC in EtOH $\left(50 \mathrm{~cm}^{3}\right)$. The complex appeared instantaneously but the reflux was maintained for $2 \mathrm{~h}$.

Dibromo bis[3-(2-furyl) 2-propenal semicarbazone] copper(II). This bromo complex was obtained like the corresponding chlorocomplex using anhydrous $\mathrm{CuBr}_{2}$ $\left(1.12 \mathrm{~g} ; 5.10^{-3} \mathrm{~mol} ; 20 \mathrm{~cm}^{3}\right)$ and FASC $\left(45 \mathrm{~cm}^{3}\right)$.

Dichloro [3-(2-furyl) 2-propenal semicarbazone] zin$c(I I)$. To FASC $\left(70 \mathrm{~cm}^{3}\right)$ was added the ethanolic solution of $\mathrm{ZnCl}_{2}\left(1.36 \mathrm{~g} ; 10^{-2} \mathrm{~mol} ; 40 \mathrm{~cm}^{3}\right)$. The complex was obtained after $3 \mathrm{~h}$ refluxing and $50 \%$ reduction of the volume under reduced pressure.

Dichloro [3-(2-furyl) 2-propenal semicarbazone] cadmium(II). Starting from FASC $\left(70 \mathrm{~cm}^{3}\right)$ and $\mathrm{CdCl}_{2}$ ( $\left.1.8 \mathrm{~g} ; 10^{-2} \mathrm{~mol} ; 35 \mathrm{~cm}^{3}\right)$, the complex precipitated down during the addition of the metallic salt. However, the solution was refluxed for $1 \mathrm{~h}$.

Dibromo [3-(2-furyl) 2-propenal semicarbazone] cadmium (II). It was obtained in the same way as the chloro derivative with FASC $\left(70 \mathrm{~cm}^{3}\right)$ and $\mathrm{CdBr}_{2} \cdot 4 \mathrm{H}_{2} \mathrm{O}\left(3.4 \mathrm{~g} ; 10^{-2} \mathrm{~mol} ; 30 \mathrm{~cm}^{3}\right)$.

\section{Physical measurements}

Elemental analyses were carried out by the Service Central d'Analyse du C.N.R.S. (Vernaison, France). Melting points were determined with a Büchi Tottoli apparatus and were not corrected. Magnetic measurements were made at $298 \mathrm{~K}$ with a magnetic balance Bruker B-SU 10 (Laboratoire de Chimie de Coordination, U.S.T.H.B., Alger, Algeria) calibrating against $\mathrm{Hg}\left[\mathrm{Co}(\mathrm{SCN})_{4}\right]$ with correction of diamagnetism. Conductance values were obtained with a Tacussel CD6NG conductimeter at $298 \mathrm{~K}$ from $10^{-3}$ mol dm ${ }^{-3}$ solutions of complexes in absolute ethanol ; the solvent had a conductance of $10^{-8} \mathrm{~S} \mathrm{~cm}^{2} \mathrm{~mol}^{-2}$; the conductance of $\mathrm{NaI}\left(10^{-3} \mathrm{~mol} \mathrm{dm}^{-3}\right)$ was $33 \mathrm{~S} \mathrm{~cm}^{2}$ $\mathrm{mol}^{-2}$. The IR spectra were recorded with a Shimadzu FTIR-8010 M spectrophotometer between 4600 and $400 \mathrm{~cm}^{-1}$ (KBr disks) and with a Nicolet FTIR $20 \mathrm{~F}$ in the range $400-50 \mathrm{~cm}^{-1}$ using polyethylene disks (Laboratoire de Physique Cristalline, Institut des Matériaux de Nantes, France). Electronic spectra were recorded with a Perkin-Elmer Lambda 19 spectrophotometer from ethanolic or chloroformic solutions $\left(10^{-3} \mathrm{~mol} \mathrm{dm}^{-3}\right)$. The NMR spectra were obtained with a Jeol GSX 270 WB $(270 \mathrm{MHz})$ spectrophotometer in D6-D.M.S.O. solutions, using TMS as internal reference. The X-ray powder diagrams were done with a Rigaku diffractometer (Laboratoire de Géologie, Faculté des Sciences, Université d'Angers) using the $\mathrm{Cu}-\mathrm{K}_{\alpha}$ radiation $(1.5418 \AA)$; the "Dicvol 91" [17] and "Celsiz" [32] computer programs allowed us to determine and refine the main crystalline parameters.

\section{RESULTS AND DISCUSSION}

Table 1 summarizes the analytical data of the complexes. Two series are obtained corresponding to the formula :

$\left[\mathrm{M}(\mathrm{FASC})_{2} \mathrm{X}_{2}\right]$ or $\left.\left[\mathrm{M}(\mathrm{FASC})_{2}\right] \mathrm{X}_{2}\right]$ when $\mathrm{M}=\mathrm{Co}, \mathrm{Ni}$ or $\mathrm{Cu}$;

$\left[\mathrm{M}(\mathrm{FASC}) \mathrm{X}_{2}\right]$ when $\mathrm{M}=\mathrm{Zn}$ or $\mathrm{Cd}$.

The low molar conductances show that most of the complexes are non-ionic in ethanol. Moreover, the complexes obtained with $\mathrm{CoBr}_{2}$ and $\mathrm{NiBr}_{2}$ are ionic species in ethanol because their molar conductances are higher than that of NaI (Table 1).

\section{Infrared spectra}

The main vibration bands of the ligand and the complexes are reported in Table 2 .

As the potential coordinating atoms are $\mathrm{N}(8), \mathrm{N}(9)$, $\mathrm{N}(11), \mathrm{O}$ (keto) and $\mathrm{O}$ (ring), we have to look at the main vibrations of the bonds including these atoms. The ligand exhibits a broad $\mathrm{N}(11) \mathrm{H}_{2}$ stretching vibration band at $3460 \mathrm{~cm}^{-1}$ (symmetric) and 3275 $\mathrm{cm}^{-1}$ (antisymmetric) while the $v(\mathrm{~N}(9) \mathrm{H}$ ) appears in the $3100-3250 \mathrm{~cm}^{-1}$ region. In addition, no band which might be due to $v(\mathrm{O}-\mathrm{H})$ of an enolic form is observed above $3500 \mathrm{~cm}^{-1}[8,18]$. This clearly establishes that FASC actually exists only in the keto form as indicated in Fig. 1. On the other hand, the ring vibrations, e.g. ring breathing or $\delta(\mathrm{C}-\mathrm{O}-\mathrm{C})$ are typical of 2-substituted furans [19].

In the spectra of the complexes several modifications occur. The $v(\mathrm{C}=\mathrm{O})$ band is slightly shifted 
Table 1. Analytical data

\begin{tabular}{|c|c|c|c|c|c|c|c|c|}
\hline \multirow[b]{2}{*}{ Compound } & \multirow[b]{2}{*}{ Colour } & \multirow{2}{*}{$\begin{array}{l}\text { M.P. } \\
\left({ }^{\circ} \mathrm{C}\right)\end{array}$} & \multicolumn{4}{|c|}{ Elemental analysis Found (Calc.) \% } & \multirow{2}{*}{$\begin{array}{c}\mu \\
\text { (B.M.) }\end{array}$} & \multirow{2}{*}{$\mathrm{m}^{2} \mathrm{~mol}^{-1}$} \\
\hline & & & $\mathrm{C}$ & $\mathbf{H}$ & $\mathbf{M}$ & $\mathrm{X}$ & & \\
\hline$\left[\mathrm{CoCl}_{2}(\mathrm{FASC})_{2}\right]$ & green & 252 & $39.1(39.4)$ & $3.7(3.7)$ & $12.0(12.1)$ & $14.2(14.4)$ & 4.90 & 26.1 \\
\hline$\left[\mathrm{CoBr}_{2}(\mathrm{FASC})_{2}\right]$ & green & 264 & $33.5(33.4)$ & $3.3(3.2)$ & $10.1(10.2)$ & $27.4(27.4)$ & 4.87 & 30.8 \\
\hline$\left[\mathrm{NiCl}_{2}(\mathrm{FASC})_{2}\right]$ & $\tan$ & $>300$ & $39.2(39.5)$ & $3.8(3.7)$ & $12.1(11.9)$ & $14.3(14.4)$ & 3.19 & 23.5 \\
\hline$\left[\mathrm{NiBr}_{2}(\mathrm{FASC})_{2}\right]$ & $\tan$ & $>300$ & $33.2(33.4)$ & $3.2(3.3)$ & $10.1(10.0)$ & $27.5(27.4)$ & 3.21 & 51.1 \\
\hline$\left[\mathrm{CuCl}_{2}(\mathrm{FASC})_{2}\right]$ & $\tan$ & 184 & $39.1(39.1)$ & $3.8(3.7)$ & $12.7(12.8)$ & $14.2(14.3)$ & 1.96 & 10.2 \\
\hline$\left[\mathrm{CuBr}_{2}\left(\mathrm{FASC}_{2}\right]\right.$ & brown & 175 & $33.1(33.2)$ & $3.1(3.1)$ & $10.8(10.9)$ & $27.2(27.3)$ & 1.85 & 9.7 \\
\hline$\left[\mathrm{ZnCl}_{2}(\mathrm{FASC})\right]$ & brown & 243 & $30.7(30.7)$ & $3.0(2.9)$ & $20.3(20.4)$ & $22.1(22.3)$ & diam. & 3.7 \\
\hline$\left[\mathrm{CdCl}_{2}(\mathrm{FASC})\right]$ & $\tan$ & 272 & $26.5(26.5)$ & $2.6(2.5)$ & $30.0(31.4)$ & $18.7(19.3)$ & diam. & 5.0 \\
\hline$\left[\mathrm{CdBr}_{2}(\mathrm{FASC})\right]$ & $\tan$ & 242 & $21.3(21.3)$ & $2.1(2.0)$ & $22.7(25.3)$ & $33.9(35.0)$ & diam. & 7.0 \\
\hline
\end{tabular}

to lower wave numbers in $\mathrm{Cd}^{\mathrm{II}}, \mathrm{Ni}^{\mathrm{II}}$ and $\mathrm{Co}^{\mathrm{II}}$ complexes and highly shifted in the other complexes. The ring breathing vibration band is shifted to higher wave numbers in the former and remains quite unchanged in the latter.

The metal-halogen stretching vibrations are observed in the spectra of the complexes [20]. In addition, the $\mathrm{Co}^{\mathrm{II}}, \mathrm{Ni}^{\mathrm{II}}$ and $\mathrm{Cd}^{\mathrm{II}}$ complexes exhibit a typical $v(\mathrm{M}-\mathrm{N})$ vibration band [21(a)]. The $\mathrm{Cu}^{\mathrm{II}}$ and $\mathrm{Zn}^{\text {II }}$ species show a metal-oxygen vibration band around $360 \mathrm{~cm}^{-1}$ corresponding to a keto oxygen atom [21(b)]. On the opposite side, the stretching vibration band of the carbon-nitrogen double bond of the azomethine group is always slightly shifted.

Some dimeric structures have been characterized in the case of copper ${ }^{(I)}$ complexes with, for instance, the semicarbazones derived from isatin benzoin and 2 hydroxynaphthaldehyde [12]. But, we note that there is neither metal-metal stretching vibration band nor bridging metal-halogen vibration band [21] in our spectra. This indicates that these compounds are mononuclear species.

We note that FASC acts as a bidentate ligand through the $\mathrm{N}$ from the azomethine moiety in all cases and the $\mathrm{O}$ furanic atom in the case of cobalt, nickel and cadmium complexes or the $\mathrm{O}$ keto atom in the case of copper and zinc complexes whatever the number of FASC to be bound to the cation.

\section{Electronic spectra}

The electronic spectrum of the ligand presents no absorption in the visible and near IR region. The magnetic momentum (Table 1) indicate that the complexes are high spin species.

The spectra of the cobalt complexes show three bands respectively at $7390,16,070$ and $18,530 \mathrm{~cm}^{-1}$ $\left(\mathrm{Cl}^{-}\right)$and $7410,15,960$ and $17,920 \mathrm{~cm}^{-1}\left(\mathrm{Br}^{-}\right)$. The use of König's relations [22] lead to relative values of $10 \mathrm{Dq}: 8590 \mathrm{~cm}^{-1}\left(\mathrm{Cl}^{-}\right)$and $8510 \mathrm{~cm}^{-1}\left(\mathrm{Br}^{-}\right)$while the Racah's $B$ parameters are equal to $815 \mathrm{~cm}^{-1}$ and $770 \mathrm{~cm}^{-1}$ respectively and the $\beta$ ratio $(\beta=\mathrm{B}$ free gaseous ion/B complex) is 0.84 and 0.79 . In addition, the $v_{1} / v_{2}$ ratios : 2.17 for $\mathrm{Cl}^{-} ; 2.15$ for $\mathrm{Br}^{-}$, are located in the correct range for the attribution of the $3 d-d$ transition bands. Overall, the calculated and experimental values of the three $d-d$ bands are quite identical and these values agree with a trans dihalogeno octahedral structure of the complexes [23(a)].

For the nickel(II) complexes the 3 bands are observed at $8465,13,340$ and $22,785 \mathrm{~cm}^{-1}$ in the case of $\mathrm{Cl}^{-}$and $7925,13,525$ and $22,190 \mathrm{~cm}^{-1}$ for $\mathrm{Br}^{-}$. The first band is equal to $10 \mathrm{Dq}$. The calculated $\mathbf{B}$ values are respectively $737 \mathrm{~cm}^{-1}(\beta=0.71)$ and 765 $\mathrm{cm}^{-1}(\beta=0.73)$. On the other hand there is no significant difference between experimental and calculated values of $v_{1}, v_{2}$, and $v_{3}$. These values are in good agreement with those of trans dihalogeno octahedral structures [23(b)].

Finally for the copper(II) derivatives, the broad $d$. $d$ absorption bands are located respectively at 13200 $\mathrm{cm}^{-1}$ for the chloride and $12,600 \mathrm{~cm}^{-1}$ for the bromide compound. This position is typical of a distorted octahedral structure [23(c)]. Moreover, the $10 \mathrm{Dq}$ for the chloride derivative was calculated at $7125 \mathrm{~cm}^{-1}$ using Billing's equation [24]. This however was not possible in the case of the bromide complex because of the absence of shoulder bands.

\section{NMR spectra}

The NMR spectra $\left({ }^{1} \mathrm{H}\right.$ and $\left.{ }^{13} \mathrm{C}\right)$ of the ligand FASC and the diamagnetic species $\left[\mathrm{ZnCl}_{2}\right.$ (FASC)], $\left[\mathrm{CdCl}_{2}\right.$ (FASC)] are reported in Table 3 .

${ }^{1} \mathrm{H}$ and ${ }^{13} \mathrm{C}$ resonances were attributed using heteronuclear correlations in ${ }^{2} J$ and ${ }^{3} J$ determined from the H.M.B.C. spectra of the compounds are presented in Fig. 2. The $\mathrm{H}(5)-\mathrm{H}(6)$ coupling constant is $16 \mathrm{~Hz}$ while its value is $8 \mathrm{~Hz}$ for $\mathrm{H}(6)-\mathrm{H}(7)$. Consequently the geometry around the $\mathrm{C}(5)$ and $\mathrm{C}(6)$ double bond is a trans arrangement and the single bond character of $C(6)-C(7)$ is confirmed [25]. These values remained unchanged in the case of both the complexes.

The ${ }^{1} \mathrm{H}$ spectra do not show significant differences 


\begin{tabular}{|c|c|c|c|c|c|c|c|c|c|}
\hline$\frac{1}{2}$ & 11 & 1 & 1 & 1 & $\Sigma$ & 品 & $\vec{ల}$ & 1 & I \\
\hline$\frac{1}{2}$ & | $\overrightarrow{\mathrm{g}}$ & \& & $F$ & $\stackrel{\circ}{\square}$ & 1 & 1 & & 产 & \&े \\
\hline$\infty$ & 1 芯 & $\stackrel{\circ}{\circ}$ & $\underset{\sim}{\circ}$ & సิ & $\bar{N}$ & $\underset{N}{\stackrel{R}{N}}$ & \pm & $\stackrel{\infty}{\infty}$ & $\stackrel{\infty}{\sim}$ \\
\hline$\sum$ & $1 \stackrel{\circ}{~}$ & $\check{n}$ & $\hat{a}$ & $\approx$ & $\bar{్}$ & $\stackrel{i}{i}$ & $\infty$ & प्रे & $\stackrel{n}{n}$ \\
\hline$\frac{5}{5}$ & 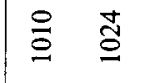 & $\stackrel{\widetilde{\Xi}}{\cong}$ & : & ฐ̃ & $\stackrel{\infty}{\Xi}$ & $\stackrel{N}{\Xi}$ & $\stackrel{\circ}{\varrho}$ & $\stackrel{\Delta}{\Xi}$ & $\stackrel{\Xi}{\Xi}$ \\
\hline$z_{z}^{\infty}$ & 志 & $\Sigma$ & 菏 & 志 & $\stackrel{2}{2}$ & \& & \& & I & $\tilde{\sigma}$ \\
\hline$=$ & $\cong \stackrel{\infty}{\Xi}$ & $\stackrel{\infty}{=}$ & $\stackrel{\infty}{=}$ & & $\stackrel{\infty}{=}$ & $\stackrel{\infty}{=}$ & $\stackrel{\infty}{=}$ & $\stackrel{\tilde{\alpha}}{\underline{a}}$ & $\stackrel{ \pm}{\Xi}$ \\
\hline 迨 & 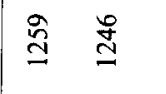 & $\stackrel{ \pm}{\Xi}$ & $\stackrel{?}{\beth}$ & $\stackrel{0}{d}$ & $\tilde{\Xi}$ & 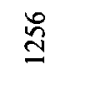 & & 蒿 & ฐ̃ \\
\hline 8 & 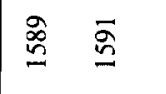 & $\overline{\bar{\sigma}}$ & $\underline{0}$ & $\overline{8}$ & 总 & $\bar{\partial}$ & & D. & $\stackrel{0}{2}$ \\
\hline 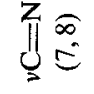 & $\stackrel{\mathscr{B}}{\mathbb{\sigma}}$ & $\stackrel{\infty}{\varrho}$ & త్ర్తి & $\stackrel{\infty}{\varrho}$ & $\stackrel{\infty}{\stackrel{\infty}{0}}$ & $\stackrel{\infty}{\underline{\Phi}}$ & & $\tilde{\Xi}$ & త్రి \\
\hline & 芯 & $\underline{\tilde{\Xi}}$ & 蒿 & $\stackrel{\varkappa}{\varrho}$ & $\underline{\underline{z}}$ & $\underline{\underline{f}}$ & & & $\underline{\hat{\theta}}$ \\
\hline 政 & 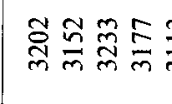 & $\bar{n}=\bar{m}=$ & $\equiv$ & $n \bar{x}=$ & 쿵 궁 & 궁 & & 第登 & $\approx$ \\
\hline & 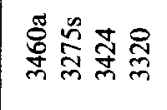 & ఫ్లి శ్లి & 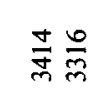 & $\underset{f}{ \pm 灬}$ & & 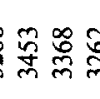 & 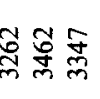 & 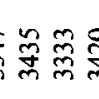 & 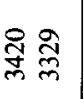 \\
\hline & 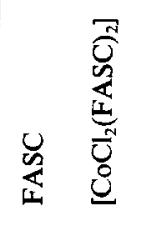 & 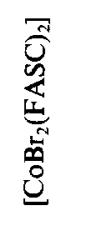 & 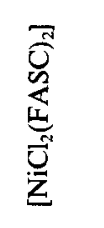 & 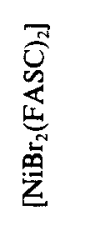 & 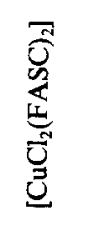 & 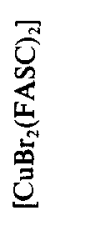 & 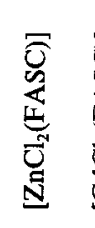 & 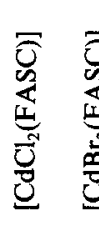 & \\
\hline
\end{tabular}




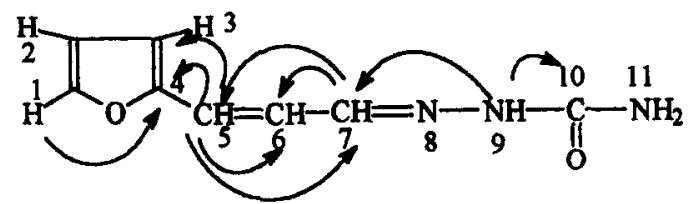

Fig. 2. ${ }^{1} \mathrm{H} /{ }^{13} \mathrm{C}$ couplings observed in the H.M.B.C. spectrum of FASC.

between the ligand and its complexes: neither chemical shifts nor coupling constants and multiplicity of the signals are perturbed by the chelation. This enhances the hypothesis that $\mathrm{N}(11)$ and $\mathrm{N}(9)$ are not coordinating atoms but the ligand is bonded with $\mathrm{N}(8)$ atom, as demonstrated on the basis of infrared spectra.

The chemical shifts observed in ${ }^{13} \mathrm{C}$ spectra (Table 3) of the complexes do not differ from those of FASC. These values are in good agreement with those given for similar compounds $[2,26,27]$. However, the relative intensities are modified : e.g. for $\mathrm{C}(10)$, the relative intensities are $86 \%$ in FASC against $24 \%$ and $68 \%$ respectively for $\left[\mathrm{ZnCl}_{2}(\mathrm{FASC})\right]$ and $\left[\mathrm{CdCl}_{2}(\mathrm{FASC})\right]$ (see Fig. 2). The keto $\mathrm{O}$ atom is therefore the coordinating atom in the case of $\left[\mathrm{ZnCl}_{2}(\mathrm{FASC})\right]$ only, and for the $\mathrm{Cd}^{\text {II }}$ compound the heterocyclic $\mathrm{O}$ is the second coordinating atom. Moreover, the $\mathrm{C}(5), \mathrm{C}(6)$ and $\mathrm{C}(7)$ atoms are the more affected by this coordination. In addition, $\mathrm{C}(1), \mathrm{C}(2)$ and $\mathrm{C}(3)$ relative intensities are shifted to lower values for the $\mathrm{Cd}^{\mathrm{II}}$ complex than for the $\mathrm{Zn}^{\mathrm{II}}$ compound.

These observations confirm (i) that the ligand shows a keto form and not an enolic one, and (ii) confirm our identification of coordinating atoms which was done on the basis of infrared spectra.

\section{Powder diffraction}

As very few compounds in these series of furanic complexes could give single crystals $[28,29]$, we have chosen to carry out $\mathrm{X}$-ray powder diffraction analysis.

The main parameters of the unit cell were determined with the "Dicvol 91" program [17]. The quantitative figure of merit $F_{N}$, where $N$ is the number of lines used in the computation, should be as high as possible [30] since $F_{N}=100$ means that the average discrepancy in $2 \theta$ calculation was $\leqslant 0.01^{\circ}$. In our data, $F_{N}$ lies from 17.5 to 7.7 meaning that the mean discrepancies in $2 \theta$ values lie in a range of $0.06-0.13^{\circ}$. This was obtained from the lines with highest intensities. The successive dichotomy method for indexing low symmetry lattices [31] indicates a triclinic system for the whole series.

The refined parameters using "Celsiz" [32] program are reported in Table 4. This table shows that the $\mathrm{CoBr}_{2}, \mathrm{CuCl}_{2}, \mathrm{CuBr}_{2}$ complexes are likely to be isostructural. The two compounds $\left[\mathrm{CoCl}_{2}(\mathrm{FASC})_{2}\right]$ and $\left[\mathrm{CdBr}_{2}(\mathrm{FASC})\right]$ show higher values of the cell unit volume, the two cupric compounds exhibit almost the 
(2)
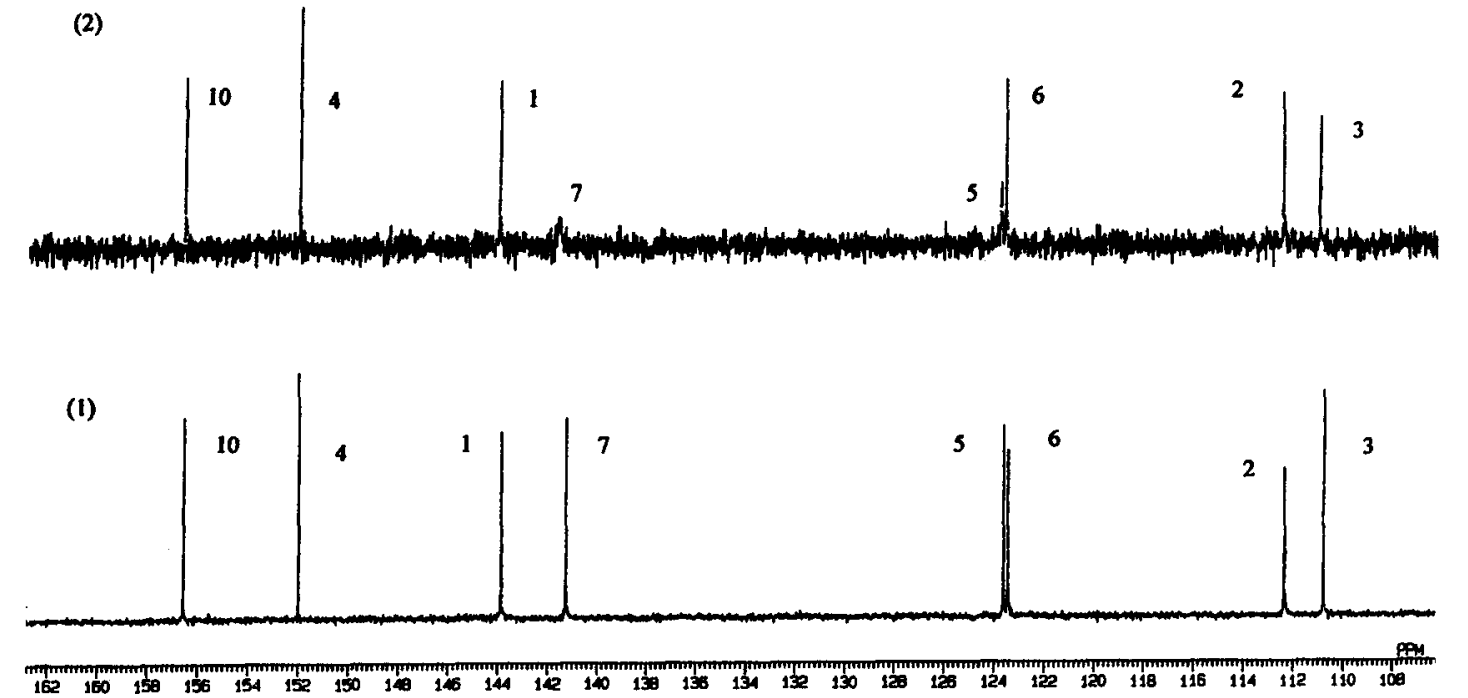

Fig. 3. ${ }^{13} \mathrm{C}$ NMR spectra of FASC (1) and $\left[\mathrm{CdCl}_{2}\right.$ (FASC)] (2).

Table 4. Refined cell parameters calculated from X-ray powder diagrams

\begin{tabular}{|c|c|c|c|c|c|c|c|}
\hline Compound & $a(\AA)$ & $b(\AA)$ & $c(\AA)$ & $\alpha\left({ }^{\circ}\right)$ & $\beta\left(^{\circ}\right)$ & $\gamma\left({ }^{\circ}\right)$ & $V\left(\AA^{3}\right)$ \\
\hline$\left[\mathrm{CoCl}_{2}(\mathrm{FASC})_{2}\right]$ & 11.960 & 12.053 & 12.935 & 108.27 & 96.44 & 108.91 & 1559.1 \\
\hline$\left[\mathrm{CoBr}_{2}(\mathrm{FASC})_{2}\right]$ & 8.484 & 9.330 & 11.178 & 88.08 & 69.01 & 83.82 & 821.3 \\
\hline$\left[\mathrm{NiCl}_{2}(\mathrm{FASC})_{2}\right]$ & 7.674 & 8.473 & 10.940 & 102.44 & 96.77 & 111.18 & 632.3 \\
\hline$\left[\mathrm{NiBr}_{2}(\mathrm{FASC})_{2}\right]$ & 6.324 & 8.217 & 11.117 & 96.31 & 106.46 & 105.33 & 523.5 \\
\hline$\left[\mathrm{CuCl}_{2}(\mathrm{FASC})_{2}\right]$ & 6.782 & 11.983 & 13.055 & 62.82 & 87.63 & 82.94 & 981.8 \\
\hline$\left[\mathrm{CuBr}_{2}(\mathrm{FASC})_{2}\right]$ & 7.224 & 12.377 & 12.583 & 66.49 & 73.83 & 87.64 & 987.8 \\
\hline$\left[\mathrm{CdBr}_{2}(\mathrm{FASC})\right]$ & 8.031 & 12.379 & 13.022 & 62.98 & 79.45 & 75.16 & 1111.4 \\
\hline
\end{tabular}

same volume and the nickel(II) species present the smallest volumes. The highest volumes are correlated with higher values of $\alpha$ or $\beta$ for $\left[\mathrm{CoCl}_{2}(\mathrm{FASC})\right]$ and $\mathrm{CdBr}_{2}$ (FASC)] or $\gamma$ in the case of cupric complexes. In addition, the bromide complexes $\left[\mathrm{CoBr}_{2}(\mathrm{FASC})_{2}\right]$ and $\left[\mathrm{NiBr}_{2}(\mathrm{FASC})_{2}\right]$ exhibit smaller unit cells than analogous chloride species. In the mean time, these two compounds are the most ionic species in this series (see Table 1).

Compared with the case of single crystal analysis obtained with simple oximes (e.g. 2-furfuraldoxime) [29], the cell parameters remain in the same magnitude. In addition, though the relative intensities of the bands could obviously be different, the powder diagrams are closely similar to those observed with metallic complexes obtained with 2-furfuraldoxime and 2-thiophene aldoxime and $\mathrm{FeX}_{2}, \mathrm{NiX}_{2},(\mathrm{X}=\mathrm{Cl}$ or $\mathrm{Br}$ ) [33] : the position of the main bands and their relative intensities are comparable.

\section{CONCLUSIONS}

We have synthesized and characterized seven new metallic complexes with 3-(2-furyl) 2-propenal semicarbazone (FASC) and $d$ element halides. On the basis of analytical data, we have noted that they are non-ionic complexes and formulated as: [M(FA$\left.\mathrm{SC})_{2} \mathrm{X}_{2}\right], \quad\left[\mathrm{M}(\mathrm{FASC})_{2}\right] \mathrm{X}_{2}$ and $\left[\mathrm{M}(\mathrm{FASC}) \mathrm{X}_{2}\right]$. The spectral data indicated that they are mononuclear trans dihalogeno octahedral species and that FASC acts as a bidentate ligand through the $\mathrm{N}$ atom of the azomethine in all species and (i) the furanic $\mathrm{O}$ atom in the case of cobalt, nickel and cadmium complexes and (ii) the keto $O$ atom for copper and zinc complexes. Indexations of the powder data led to triclinic solutions in every case.

Finally, some of these compounds such $\left[\mathrm{CuCl}_{2}(\mathrm{FASC})_{2}\right]$ exhibit a cytotoxic activity and further experiments in this connexion have been undertaken and the results are to be published shortly [34].

Acknowledgements - The authors are indebted to Professor G. Moguedet and Dr R. Biagi (Université d'Angers) for their valuable technical assistance.

\section{REFERENCES}

1. Bouet, G. and Dugué, J., Trans. Met. Chem., 1990, 15, 257. 
2. Kanoongo, N., Shingh, R. and Tandon, J. P., Trans. Met. Chem., 1988, 13, 343.

3. Garg, A. and Tandon, J. P., Trans. Met. Chem., 1987, 12, 212.

4. Howarth, G. A., Hoyle, W. and Wakefield, B. J., Talanta, 1969, 16, 967.

5. Aravindaksan, K. K. and Muraleedharan, K., Reactivity of Solids, 1990, 8, 91.

6. Puranik, V. G., Tavale, S. S., Gururow, T. N., Umapathy, P. and Budhkar, P., Acta Cryst., Sect. C, 1987, 43, 2303.

7. Cano Pavon, J. M. and Cino, F., Talanta, 1973, 20, 339.

8. Bekheit, M. M., Ibrahim, K. M. and Rakha, T. H., Bull. Soc. Chim. France, 1989, 6, 785.

9. Kumar, A., Chandra, U. and Chandra, S., Synth. React. Inorg. Met-Org. Chem., 1993, 23, 671.

10. Battaglia, L. P., Ferrari, M. B. and Boggia, R., Inorg. Chim. Acta, 1994, 215, 85.

11. Beecroft, B., Campbell, M. J. M. and Grzeskowiak, R., J. Inorg. Nucl. Chem., 1974, 36, 55.

12. Akinchan, N. T., Akinchan, R., West, D. X. and Yang, Y., Trans. Met. Chem., 1994, 19, 135.

13. Raina, R. and Srivastava, T. S., Indian J. Chem., 1983, 22A, 701.

14. Patel, P. S., Ray, R. M. and Patel, M. M., Indian J. Chem., 1993, 32A, 597.

15. West, D. X., Carlson, C. S., Whyte, A. C. and Liberta, A. E., Trans. Met. Chem., 1990, 15, 43.

16. Vogel's Textbook of Practical Organic Chemistry, eds B. S. Burniss, A. J. Hannaford, P. W. G. Smith and A. R. Tatchell, 5th edn, Longman, New York, 1989, p. 1258.

17. Louër, D., National Institute of Standards and Technology, Spec. Pub. 486, Gaithersburg, MD, U.S.A., 1992, pp. 92-104.

18. Singh, A. N., Singh, R. P., Mohanty, J. G. and Chakravorty, A., Inorg. Chem., 1977, 16, 2597.
19. Sénéchal, M. and Saugmagne, P., J. Chim. Phys. Physicochim. Biol., 1972, 69, 1246.

20. Ferraro, J. R., Low-Frequency Vibrations of Inorganic and Coordination Compounds, Plenum Press, New York, 1971.

21. (a) Nakamoto, K., Infrared and Raman Spectra of Inorganic and Coordination Compounds, 3rd edn, J. Wiley, New York, 1978, p. 216; (b) ibid., p. 308 .

22. König, E., Structure and Bonding (Berlin), 1971, 9, 175.

23. (a) Lever, A. B. P., Inorganic Electronic Spectroscopy, 2nd edn, Elsevier, Amsterdam, 1984, p. 480 ; (b) ibid, p. 508 ; (c) ibid, p. 566.

24. Billing, D. E. and Underhill, A. E., J. Inorg. Nucl. Chem., 1968, 30, 2147.

25. Canet, D., La R.M.N.: Concepts et méthodes, InterEdition-Masson, Paris, 1991, p. 43.

26. Holzer, W., Arch. Pharm. (Weinheim), 1992, 325, 769.

27. Heinisch, G. and Holzer, W., Monatsh. Chem., 1990, 121, 837.

28. Bouet, G., Thesis, University of Angers, France, 1987.

29. Noren, B., Oskarsson, A., Dash, K. D. and Mohapata, M., Acta. Cryst., 1990, C46, 2093.

30. Smith, G. S. and Snyder, R. L., J. Appl. Cryst., $1979,12,60$.

31. Boultif, A. and Louër, D., J. Appl. Cryst., 1991, 24, 987.

32. Hay, D., Celsiz, Cell Refinement Program, CSIRO, Clayton South, Australia, 1995.

33. Kuma, H. and Yamada, S., Synth. React. Inorg. Met.-Org. Chem., 1983, 13, 467.

34. Hall, I. H., Lee, C., Bouet, G. M., Ibrahim, G. and Khan, M. A., Appl. Organomet. Chem. in press (1997). 